\title{
The Moderating Role of Family Supportive Supervisor Behavior in Relationship between Work-Family Conflict and Job Satisfaction among Working Mother
}

\author{
Devy Fitria Rahmatika ${ }^{1 *}$, Endang Parahyanti ${ }^{2}$ \\ ${ }^{1,2}$ Faculty of Psychology, University of Indonesia, Depok, Indonesia \\ * E-mail: devyrahmatika@gmail.com
}

\begin{abstract}
This study aimed to prove whether work-family conflict (work interfering with family/WIF and family interfering with work/FIW) negatively related to job satisfaction and whether family supportive supervisor behavior as a moderator, could weaken the negative relationship between work-family conflict (WIF and FIW) and job satisfaction. Type of this research was quantitative research with cross-sectional design and conducted on 205 working mothers via offline and online questionnaire. Three instruments were used to measure three variables, such as WFCS to measure work-family conflict, MSQ-SF to measure job satisfaction, and FSSB Scale to measure Family Supportive Supervisor Behavior. Method of statistical analysis used in this research was simple linear regression analysis and simple moderation analysis. This research has found that work-family conflict (WIF and FIW) related negatively and significantly with job satisfaction (work interfering with family $(\beta=-.32, p<.05)$ and family interfering with work $(\beta=-.29, p<$ $.05)$ ). However, this research has not found the moderating role of family supportive supervisor behavior significantly to weaken the negative relationship between work interfering with family nor family interfering with work and job satisfaction.
\end{abstract}

\section{Keywords: family supportive supervisor behavior; job satisfaction; work-family conflict; working mother}

\section{Introduction}

BPS (2016) released that female workers in Indonesia have increased by 7.89 since 2014-2016. It showed more women left home to develop their careers even many companies were giving them the opportunity to occupy essential positions (Pujiono, 2016). However, this phenomenon was not directly proportional to job satisfaction among female workers because they tended to have lower job satisfaction than male workers (Kanwar, Singh, \& Kodwani, 2012; Kifle \& Desta, 2012). Kanwar et al. (2012) argue that it occurred as women have the essential responsibility in the family, experience role conflict, limited in mobilizing their roles, and others that make them difficult to manage responsibilities in the work and family. The impact of low job satisfaction among women was the intention to leave the organization (Kanwar et al., 2012; Lambert \&
Hogan, 2009). Furthermore, a decrease of job satisfaction will cause negative impact on employee's job performance and organization as employees do not enjoy their job, frustration, having trouble with the client, even giving negative implications toward organization (Bemana, Moradi, Ghasemi, \& Taghavi, 2013). Therefore, many researchers considered that job satisfaction is important for employee's well-being and organization's improvement. Gao, Shi, Niu, and Wang (2013) revealed that job satisfaction is an important attitudinal outcome in the workplace. Çelik (2011) also explained that level of job satisfaction and any variables which affect job satisfaction are significant factors for productivity and employee's sense of well-being toward the organization. 
According to Theory of Work Adjustment, job satisfaction was defined as satisfaction with reinforcers on the job such as pay, prestige, and work conditions (Dawis, 2005). Many factors are affecting job satisfaction, such as antecedents from environment, personal, and combination of both (Spector, 2012). Family supportive supervisor behavior and length of service were also affecting job satisfaction (Hammer, Kossek, Yragui, Bodner, \& Hanson, 2009; Odle-Dusseau, Britt, \& GreeneShortridge, 2012; Sarker, Crossman, \& Chinmeetipituck, 2013). Another factor is workfamily conflict (WFC) which will be more discussed here.

Greenhaus and Beutell (1985) defined work-family conflict as a form of inter-role conflict, occurred when role pressure from work and family domain are incompatible in some respect. Further, according to Greenhaus and Beutell, WFC can happen from work to family domain and vice versa, thus some researchers identified that WFC could be viewed in two directions (bidirectional), that is work interfering with family (WIF) and family interfering with work (FIW) (Frone, Yardley, \& Markel, 1997; Gutek, Searle, \& Klepa, as cited in Carlson, Kacmar, \& Williams, 2000; Netemeyer, Boles, \& McMurrian, 1996).

Previous studies suggested WFC can be explained by Conservation of Resource (COR) Theory (Grandey \& Cropanzano, 1999; Gao et al., 2013). It is more comprehensive to explain behavior while stress and bridge discrepancy between environmental and cognitive viewpoints (Hobfoll, 1989). The basic principle of COR Theory according to Hobfoll (1989) is the individuals attempt to maintain, protect, develop resources, and minimize any threats against valued resources. Four types of those resources are objects, personal characteristics, conditions, and energies. The situation which can cause actual loss of resources and lack of appropriate resources gain, making individuals experience stress, so that strive to minimize loss of resources by employ owned resources or resources from environment (Hobfoll, 1989).

Mostly, WFC is experienced by working mothers as they have important role in the family and workplace. Based on gender role theory, women are more likely than men, view roles in family as a part of their central social role (Gutek et al., as cited in Grandey, Cordeiro, \& Crouter, 2005). It makes women are vulnerable to have stress when attempting to integrate, manage, and doing activities from different domains at the same time (Delina \& Raya, 2013). Thus, working mothers need resources to buffer negative effect of WFC toward job satisfaction. One of many resources is social support from supervisor at workplace, especially family supportive supervisor behavior which will be studied further in this research as a moderator. Also, this research will employ working mothers as respondent based on previous explanation.

The phenomenon of WIF and FIW who are negatively related to job satisfaction can be explained by Beutell (2010) and Gao et al. (2013) based on COR Theory. According to Frone et al. (1997), WIF occurs when fulfillment responsibilities from work domain make employees difficult to meet responsibilities from family domain. Gao et al. (2013) argue that it leads them having stress because of loss of resources in work and family domains while trying to meet role demands of both fields. Stress can result in a decrease of job satisfaction. Meanwhile, FIW occurs when fulfillment responsibilities from family domain make employees difficult to meet responsibilities from work domain (Frone et al., 1997). It also leads to stress as loss of resources then could decrease job satisfaction (Gao et al., 2013). Some studies also have shown that WIF and FIW were negatively and significantly related to job satisfaction because higher WIF and FIW will decrease job satisfaction (Beutell, 2010; Gao et al., 2013; \& Rathi \& Barath, 2013). However, another research found that family-work conflict (FIW) was not related to job satisfaction because of cultural context (Anafarta, 2011; Mihelǐc, 2014). Thus, there is inconsistency of research results about relationship between WIF and FIW with job satisfaction, so that future research about it is needed. Based on explanation above, researchers argue that WIF and FIW who are experienced by working mothers can decrease job satisfaction because of stress due to loss of resources in both domains (work and family) while attempting to meet responsibilities of both domains.

Hypothesis 1a: Work interfering with family is negatively related to job satisfaction among working mother

Hypothesis 1b: Family interfering with work is negatively related to job satisfaction among working mother

\section{Moderating Role of Family Supportive Supervisor Behavior}

According to COR theory, individuals who experienced loss of resources will strive to gain resources or minimize threats against loss of resources owned (Hobfoll, 1989). One of many resources is social support from workplace, specifically supervisor support that is family 
supportive supervisor behavior (FSSB). FSSB is defined as behavior exhibited by supervisor to support employee's roles in family (Hammer, Kossek, Zimmerman, \& Daniels, 2007). It has four dimensions such as emotional support, instrumental support, role modeling behavior, and creative workfamily management (Hammer et al., 2009). Previous researches suggested that FSSB can buffer negative effect of stressful events. Hammer et al. (2007) argued that FSSB is viewed as critical resources to conquer stress while attempting to manage work and family responsibilities. Individuals with greater access to getting workplace social support (especially FSSB in this study) will gain additional psychological resources (Bakker \& Demerouti, as cited in Kossek, Pichler, Bodner, \& Hammer, 2011). Moreover, Kossek et al. (2011) suggested that it provides a buffer to stress. In other words, social support (especially FSSB) can be a protective factor against resources depletion (Hobfoll \& Shirom, as cited in Crain et al., 2014).

When employees have WIF, they will experience stress as resources depletion in the work and family domains while attempting to meet demands from both domains. Employees who perceive their supervisor exhibit FSSB, probably will not be interfered with WIF as they gain support to manage their roles in the work and family domains. As previous research results showed that FSSB was negatively related to WIF, thus FSSB would reduce WIF experienced by employees (Crain et al., 2014; Hammer et al., 2009). Therefore, FSSB probably will be buffered negative effects of WIF and is not able to expand its effects. Moreover, previous research has found FSSB also was positively related to job satisfaction wherein FSSB would increase job satisfaction (Hammer et al., 2009; Odle-Dusseau et al., 2012). It means, even though employees are experiencing WIF, their job satisfaction probably will not decrease as they gain FSSB. Hence, researchers assume that negative effects of WIF toward job satisfaction will be buffered if employees perceive their supervisor exhibit FSSB.

Hypothesis 2a: FSSB as a moderator is able to weaken negative relationship between WIF and job satisfaction among working mother

Meanwhile, related to FIW, employees who experience FIW will experience stress as resources which should be used to meet roles in work domain have been exhausted to meet role demands in family domain. Consequently, it leads to decrease their job satisfaction. However, employees who perceive their supervisor exhibit adequate FSSB, probably negative effects of FIW will be buffered and cannot expand its effects. As previous research results showed that
FSSB was negatively related to FIW, thus FSSB would reduce FIW experienced by employees (Crain et al., 2014). Moreover, as mention earlier that FSSB was positively related to job satisfaction, thus it can increase employees job satisfaction. Therefore, although FIW occurred, job satisfaction of employees probably will not decrease as they gain FSSB. Hence, researchers assume that negative effects of FIW toward job satisfaction will be buffered if employees perceive their supervisor exhibit FSSB.

Hypothesis 2b: FSSB as a moderator is able to weaken negative relationship between FIW and job satisfaction among working mother

\section{Methods}

Sample. Questionnaires were distributed via offline and online to some organizations in Jakarta. Total of questionnaires processed was 205. Respondents are working mothers full-time in an organization and have married. The age of them ranged from $24-53$ years old. Researchers also considered other characteristics which were correlated with workfamily conflict and job satisfaction in previous research, such as have a working husband (Duxburry \& Higgins, 1991), have children with age ranged from 0 - 12 years (Allen \& Finkelstein, 2014), number of children (Somech \& Drach-Zahavy, 2007), respondent's age (Demerouti, Peeters, \& van der Heijden, 2012), and length of services (Cinamon \& Rich, 2005). Respondents were gathered through nonprobability sampling, specifically convenience sampling and snowball sampling. Gravetter and Forzano (2012) defined convenience sampling is a process of selecting sample based on availability and willingness to respond as respondent in the research. Meanwhile, snowball sampling is a process gathering sample using networks (Kumar, 2011). Researcher selected some individuals to be samples of this research, then asked them to identify other individuals who meet research's criteria.

Research Design. This research is quantitative research. Based on Kumar (2011), this research design can be viewed by three different perspectives. First, based on the number of contact with study population, it is classified as cross-sectional or oneshot study since overall information is gathered at a time. Based on reference period, it is classified as retrospective study since employed data which has been available for that period or respondent's recall on that situation. Based on nature of investigation, it is classified as non-experimental design since it starting by knew the effect then sought to know the cause and researchers do not manipulate the variable. 


\section{Instrument and Measurement.}

Job Satisfaction. Job satisfaction was measured by Minnesota Satisfaction Questionnaire Short-Form (MSQ-SF) developed by Weiss, Dawis, England, and Lofquist (1967) based on Theory of Work Adjustment. It consists of 20 items to measure employee's job satisfaction toward 20 reinforcers on the job. Respondents rated the items on a six-point Likert Scale $(1=$ strongly disagree, $6=$ strongly agree). Cronbach's alpha for this instrument was 0.90 in this research. It means the instrument has a good level of reliability. Based on Kaplan and Saccuzzo (2009) reliability estimates ranged from $0.70-0.80$ are good enough for basic research.

Work-Family Conflict. WIF and FIW were measured by Work-Family Conflict Scale (WFCS) developed by Carlson et al. (2000) and obtained from Herst's dissertation (2003) which has been adapted to Indonesian by Puspita (as cited in Alwi, 2011) and used by Handini (2013). This research employed WFCS that has been adapted by Handini (2013). WIF and FIW were measured by 9 items each. Respondents rated the items on a six-point Likert Scale $(1=$ strongly disagree, $6=$ strongly agree). Cronbach's alpha for this scale was 0.84 (WIF) and 0.78 (FIW) in this research.

Family Supportive Supervisor Behavior. FSSB was measured by FSSB Scale adapted from Hammer et al. (2009). This scale consists of 14 items to measure four dimensions of FSSB such as emotional support, instrumental support, role modeling behavior, and creative work-family management. Respondents rated the items on a six-point Likert Scale $(1=$ strongly disagree, $6=$ strongly agree $)$. Cronbach's alpha for this scale was 0.90 in this research. It means this instrument is good enough for this research.

Procedure. This research was conducted by distributed offline and online questionnaire. Early before distributing offline questionnaires, researchers administered permission and proposed research proposal to the intended organization. Hereafter, questionnaire was augmented to be distributed toward some organizations that had confirmed research permission. It was distributed to employees who meet the research criteria. Researcher also met some working mothers who are recognized by researcher to participate in this research. Meanwhile, online questionnaire was distributed through messages in some social media.

\section{Results}

This research employed simple linear regression analysis to analyze relationship between WIF and FIW with job satisfaction. Statistical analysis was conducted by using total score of each research variable.

Table 1.

Correlation and Regression Result for Relationship of WIF and Job Satisfaction

\begin{tabular}{|c|c|c|}
\hline \multirow[b]{2}{*}{ Variable } & \multicolumn{2}{|c|}{ Job Satisfaction } \\
\hline & Model $1 \mathrm{~B}$ & $95 \% \mathrm{CI}$ \\
\hline Constant & $101.37 *$ & {$[95.64,107.10]$} \\
\hline $\begin{array}{l}\text { Work interfering with } \\
\text { family }\end{array}$ & $-0.50 *$ & {$[-0.70,-0.29]$} \\
\hline B & $-.32 *$ & \\
\hline $\mathrm{R}^{2}$ & .10 & \\
\hline $\mathrm{F}$ & $23.63 *$ & \\
\hline
\end{tabular}

Table 1 shows that WIF was able to predict job satisfaction, $\beta=-.32, p<.05$. Furthermore, WIF was negatively and significantly related to job satisfaction, $\mathrm{F}(1,203)=23.63, \mathrm{p}<.05$, with $\mathrm{R}^{2}=$ .10. It provides that WIF was able to be a significant predictor of job satisfaction wherein $10 \%$ of job satisfaction variances could be explained by WIF.

Table 2.

Correlation and Regression Result for Relationship of FIW and Job Satisfaction

\begin{tabular}{|c|c|c|}
\hline \multirow[b]{2}{*}{ Variable } & \multicolumn{2}{|c|}{ Job Satisfaction } \\
\hline & Model $1 \mathrm{~B}$ & $95 \% \mathrm{CI}$ \\
\hline Constant & $101.01 *$ & {$[94.9,107.13]$} \\
\hline $\begin{array}{l}\text { Family interfering } \\
\text { with work }\end{array}$ & $-0.59 *$ & {$[-0.86,-0.33]$} \\
\hline$\beta$ & $-.29 *$ & \\
\hline $\mathrm{R}^{2}$ & .08 & \\
\hline $\mathrm{F}$ & $19.52 *$ & \\
\hline
\end{tabular}

Table 2 shows that FIW was able to predict job satisfaction, $\beta=-.29, \mathrm{p}<.05$. Furthermore, FIW was negatively and significantly related to job satisfaction, $\mathrm{F}(1,203)=19.52, \mathrm{p}<.05$, with $\mathrm{R}^{2}=$ .08 . It provides that FIW was able to be a significant predictor of job satisfaction wherein $8 \%$ of job satisfaction variances could be explained by FIW. Based on the result above, it could be concluded that hypothesis $1 \mathrm{a}$ and $1 \mathrm{~b}$ were proven that is WIF and FIW were negatively and significantly related to job satisfaction. Moreover, this research found that variances of job satisfaction were greater explained by WIF than FIW. It means WIF was a stronger 
predictor of job satisfaction than FIW in this research.

Table 3.

Moderation Results of FSSB from WIF Perspective

\begin{tabular}{lcccccc}
\hline Model & Coeff & Se & t & p & LLCI & ULCI \\
\hline Constant & 87.6730 & 0.655 & 133.899 & .000 & 86.382 & 88.964 \\
TFSSB & 0.660 & 0.058 & 11.048 & .000 & 0.542 & 0.778 \\
WIF & -0.215 & 0.100 & -2.149 & .033 & -0.412 & -0.018 \\
int_1 & -0.003 & 0.008 & -0.371 & .711 & -0.018 & 0.012 \\
\hline
\end{tabular}

Note: TFSSB = Total Family Supportive Supervisor Behavior. WIF = Work Interfering with Family. Int $1=$ interaction of TFSSB and WIF

Simple moderation analysis by HAYES PROCESS was conducted to analyze moderation role of FSSB in relationship between WIF and FIW to job satisfaction. Table 3 shows that WIF was negatively and significantly related to job satisfaction (b1 = $0.215, p=.033)$. FSSB was found had positive and significant relationship with job satisfaction $(\mathrm{b} 2=$ $.660, p=.000)$. The main result of this analysis shows that FSSB was not able to be significant moderator in relationship between WIF and job satisfaction $(b 3=-0.003, p=.711)$.

Table 4.

Moderation Results of FSSB from FIW Perspective

\begin{tabular}{lcccccc}
\hline Model & Coeff & Se & $\mathbf{t}$ & $\mathbf{p}$ & LLCI & ULCI \\
\hline Constant & 87.689 & 0.615 & 142.594 & .000 & 86.477 & 88.902 \\
TFSSB & 0.671 & 0.056 & 12.075 & .000 & 0.562 & 0.781 \\
FIW & -0.373 & 0.123 & -3.045 & .003 & -0.615 & -0.132 \\
int_1 & -0.005 & 0.011 & -0.439 & .661 & -0.027 & 0.017 \\
\hline
\end{tabular}

Note: TFSSB $=$ Total Family Supportive Supervisor Behavior. WIF = Work Interfering with Family. Int $1=$ interaction of TFSSB and WIF

Table 4 shows that FIW was negatively and significantly related to job satisfaction $(\mathrm{b} 1=-0.373$, $p=.003)$. FSSB had positive and significant relationship with job satisfaction $(\mathrm{b} 2=0.671, p=$ .000 ). The main result shows that FSSB was not able to be a significant moderator in relationship between FIW and job satisfaction $(b 3=-0.005, p=.661)$. Based on the main result of simple moderation analyses, it can be concluded that hypothesis $2 \mathrm{a}$ and $2 \mathrm{~b}$ were not proven because FSSB was not able to buffer negative effect of WIF and FIW toward job satisfaction, so that job satisfaction would keep decline though employees perceived they had gained FSSB.

\section{Discussion \& Conclusion}

Discussion. This research found that WIF and FIW were negatively and significantly related to job satisfaction. As well as previous research which had proven negative relationship between WIF and FIW with job satisfaction (Beutell, 2010; Gao et al., 2013; Rathi \& Barath, 2013). As suggested by Gao et al. (2013) based on COR Theory, both WIF and FIW among employees will lead to stress because of resources depletion in the work and family domain. Consequently, stress will decrease their job satisfaction. Grandey and Cropanzano (1999) suggested that COR could provide an understanding about WFC (WIF and FIW) and its implication for the attitude and behavior. Moreover, it explains the mechanism of stressful situation which leads to stress.

Another main result is moderating role of FSSB. This research has not found moderating role of FSSB in relationship between WIF and FIW with job satisfaction. Statistically, it might occur as coefficient regression of WIF/FIW, and FSSB interaction toward job satisfaction was not significant. Hayes (2013) argued that it does not mean the moderator variable (FSSB) could not act as a moderator because sometimes the real moderator's effect is too weak, so that difficult to identify its effect. Theoretically, it might occur as three possible causes. First, medium level of WIF and FIW among working mother in this research, so they did not feel FSSB from supervisor overly because psychological support has not needed yet. Hammer, Kossek, Anger, Bodner, and Zimmerman (2011) argued that employees who experience higher levels of work-tofamily conflict and family-to-work conflict will have greater need for psychological support. Hobfoll (2002) also argued that positive impact of various resources would be limited during low-stress periods. Second, differences in job characteristics and organizational policies where respondents work might affect the extent to which supervisor could provide supports to overcome WIF and FIW among respondents in this research. It might be one of the limitations in this research because respondents came from various job and organizations. Ismail, Suhaimi, Bakar, and Alam (2013) explained that differences in employee's background create different views and judgments about supervisor's ability to provide help to resolve role conflicts among employees with different job categories. Third, there were individual differences in ability and willingness to carry out suggestions from supervisor to resolve conflict who were being faced. It is supported by Ismail et al. (2013) that individual differences among employees in their ability and 
willingness to adhere directions or suggestions from supervisors related to role conflict solutions, may affect the effectiveness of social support from supervisors.

Given of this research result about moderation role of FSSB, researchers suppose that there are other potential variables which may be able to moderate relationship between WIF and FIW with job satisfaction. Wang (as cited in Gao et al., 2013) suggested six categories of resources based on stress-coping perspective, such as physical resources (e.g. muscle strength), financial resources (e.g. income), social resources (e.g. social support), cognitive resources (e.g. intelligence), emotional resources (e.g. mood), and motivational resources (e.g. goal orientation). Another potential variable is problem-focused coping strategies (Lazarus \& Folkman, as cited in Lapierre \& Allen, 2006). Problem-focused coping is appropriate for individuals who have little or no social support so that it will depend on their ability to find ways to keep family and work's life in balance (Lapierre \& Allen, 2006).

Researchers conducted twice reliability test and found it should be eliminated an item in WFCS as it had corrected item-total correlation (crit) below $0.20(\mathrm{r}<0.20)$ on the final test. It means that the item could not discriminate one individual with another. Nunnally and Bernstein (1994) suggested that reliability coefficient will increase if items can discriminate enough $(\mathrm{r}>0.20)$. Nunnally and Bernstein added that negative sign means there is bad wording or sampling error. The extent to which an item of WFCS should be eliminated was a limitation of this research. However, this research had eliminated bad item and using good items to be processed.

Based on research result, there are three implications. For theoretical implications, this research suggests future research keep using COR Theory and expand research about another resource in COR Theory. It is because of COR Theory can be a relevant, comprehensive theoretical framework to explain WFC phenomenon and its implications. Moreover, future research should expand another variable as discussed earlier which may be more able to buffer negative relationship of WIF and FIW to job satisfaction.

For methodological implications, future research should notice about translation of the instrument for measuring variables and conform it to cultural context where research is conducted. Moreover, future research should equate the proportion of samples from an organization to other organizations to makes it balance or future research focusing research only on a field of work or an organization. It is expected that FSSB will be able moderating relationship between WIF and FIW with job satisfaction significantly.

Third, this research provides important practical implications related to research result that WIF and FIW decreased job satisfaction among working mothers. For working mother, it should be better to find appropriate resources from inside (personal, such as having a good problem-focused coping) and outside (environment, such as getting support from coworker and family, to replace lost resources due to WFC, so it does not decrease job satisfaction. For organizations, should be better to facilitate intervention about work-life balance especially for female workers, such as training about the ways to manage responsibilities in work and family domain so that they will have skill in work and life balance. Moreover, organization is expected to create special policies for female workers, such as provide adequate day-care facilities and breastfeeding room, work hour flexibility, and giving special permission to take care children who are sick. Those are expected to maintain stability of job satisfaction among female workers so that their job performance will be better and able to increase organization's productivity.

Conclusions. This research has found that WIF and FIW were negatively and significantly related to job satisfaction among working mothers. However, this research has not found the role of FSSB as a significant moderator in relationship between WIF and FIW to job satisfaction among working mothers.

\section{References}

Anafarta, N. (2011). The relationship between work-family conflict and job satisfaction: A structural equation modeling (SEM) approach. International Journal of Business and Management, 6(4), 168-177.

Alwi, R. H. (2011). Hubungan antara konflik kerja-keluarga dan kelelahan kerja pada ibu yang bekerja sebagai perawat rumah sakit (Skripsi). Universitas Indonesia, Depok.

Badan Pusat Statistik. (2016). Keadaan pekerja di Indonesia Agustus 2016. Retrieved from http://microdata.bps.go.id/mikrodata/index.php/citations/4 23

Bemana, S., Moradi, H., Ghasemi, M., Taghavi, S. M., \& Ghayoor, A. H. (2013). The relationship among job stress and job satisfaction in municipality personnel in Iran. World Applied Sciences Journal, 22(2), 233-238.

Beutell, N. J. (2010). Work schedule, work schedule control, and satisfaction in relation to work-family conflict, workfamily synergy, and domain satisfaction. Career Development International, 15(5), 501-518. 
Carlson, D. S., Kacmar, K. M., \& Williams, L. J. (2000). Construction and initial validation of a multidimensional measure of work-family conflict. Journal of Vocational Behavior, 56(2), 249-276.

Çelik, M. (2011). A theoretical approach to the job satisfaction. Polish Journal of Management Studies, 4, 7 14.

Crain, T. L., Hammer, L. B., Bodner, T., Kossek, E. E., Moen, P., Lilienthal, R., \& Buxton, O. M. (2014). Work-family conflict, family-supportive supervisor behaviors (FSSB), and sleep outcomes. Journal of Occupational Health Psychology, 19(2), 155.

Dawis, R. V. (2005). The Minnesota Theory of Work Adjustment In. Brown, S. D. \& Lent, R. W (Ed.), Career Development and Counseling: Putting Theory and Research to Work (3-23). Hoboken: John Wiley \& Sons, Inc.

Delina, G. \& Raya, R. P. (2013). A study on work-life balance in working women. International Journal of Commerce, Business, and Management, 2, 1-9.

Frone, M. R., Yardley, J. K., \& Markel, K. S. (1997). Developing and testing an integrative model of the workfamily interface. Journal of Vocational Behavior, 50(2), 145-167.

Gao, Y., Shi, J., Niu, Q., \& Wang, L. (2013). Work-family conflict and job satisfaction: Emotional intelligence as a moderator. Stress and Health, 29(3), 222-228.

Greenhaus, J. H., \& Beutell, N. J. (1985). Sources of conflict between work and family roles. Academy of Management Review, 10(1), 76-88.

Grandey, A. A., \& Cropanzano, R. (1999). The conservation of resources model applied to work-family conflict and strain. Journal of Vocational Behavior, 54(2), 350-370.

Grandey, A., Cordeiro, B., \& Crouter, A. (2005). A longitudinal and multi-source test of the work-family conflict and job satisfaction relationship. Journal of Occupational and Organizational Psychology, 78(3), 305-323.

Gravetter, F. J. \& Forzano, L. B. (4 ${ }^{\text {th }}$ Ed.). (2012). Research Methods for the Behavioral Sciences. Wadsworth: Cengage Learning.

Hammer, L. B., Kossek, E. E., Zimmerman, K., \& Daniels, R. (2007). Clarifying the construct of family-supportive supervisory behaviors (FSSB): A multilevel perspective. In Exploring the work and non-work interface (pp. 165204). Emerald Group Publishing Limited.

Hammer, L. B., Kossek, E. E., Yragui, N. L., Bodner, T. E., \& Hanson, G. C. (2009). Development and validation of a multidimensional measure of family supportive supervisor behaviors (FSSB). Journal of Management, 35(4), 837-856.

Hammer, L. B., Kossek, E. E., Anger, W. K., Bodner, T., \& Zimmerman, K. L. (2011). Clarifying work-family intervention processes: The roles of work-family conflict and family-supportive supervisor behaviors. Journal of Applied Psychology, 96(1), 134

Handini, R. E. (2013). Hubungan antara work-family conflict dan keterikatan kerja pada ibu bekerja (Skripsi). Universitas Indonesia, Depok.
Hayes, A. F. (2013). Introduction to mediation, moderation, and conditional process analysis. New York: The Guilford Press.

Hobfoll, S. E. (1989). Conservation of resources: A new attempt at conceptualizing stress. American Psychologist, 44(3), 513.

Hobfoll, S. E. (2002). Social and psychological resources and adaptation. Review of General Psychology, 6(4), 307.

Ismail, A., Suhaimi, F. F., Bakar, R. A., \& Alam, S. S. (2013). Job stress with supervisor's social support as a determinant of work intrusion on family conflict. Journal of Industrial Engineering and Management, 6(4), 11881209.

Kaplan, R. M. \& Saccuzzo, D. P. (7 ${ }^{\text {th }}$ Ed.). (2009). Psychological testing: Principles, applications, and issues. Wadsworth: Cengage Learning.

Kanwar, Y. P. S., Singh, A. K., \& Kodwani, A. D. (2012). A study of job satisfaction, organizational commitment and turnover intent among the IT and ITES sector employees. Vision, 16(1), 27-35

Kifle, T., \& Desta, I. H. (2012). Gender differences in domains of job satisfaction: Evidence from doctoral graduates from Australian universities. Economic Analysis and Policy, 42(3), 319-338.

Kossek, E. E., Pichler, S., Bodner, T., \& Hammer, L. B. (2011). Workplace social support and work-family conflict: A meta-analysis clarifying the influence of general and work-family-specific supervisor and organizational support. Personnel Psychology, 64(2), 289-313.

Lambert, E., \& Hogan, N. (2009). The importance of job satisfaction and organizational commitment in shaping turnover intent: A test of a causal model. Criminal Justice Review, 34(1), 96-118.

Lapierre, L. M., \& Allen, T. D. (2006). Work-supportive family, family-supportive supervision, use of organizational benefits, and problem-focused coping: implications for work-family conflict and employee wellbeing. Journal of Occupational Health Psychology, 11(2), 169.

Mihelǐc, K. K. (2014). Work-family interface, job satisfaction, and turnover intention: a CEE transition country perspective. Baltic Journal of Management, 9(4), 446466.

Netemeyer, R. G., Boles, J. S., \& McMurrian, R. (1996). Development and validation of work-family conflict and family-work conflict scales. Journal of applied psychology, 81(4), 400.

Nunnally, J. C. \& Bernstein, I. ( ${ }^{\text {rd }}$ Ed.). (1994). Psychometric theory. USA: McGraw-Hill, Inc.

Odle-Dusseau, H. N., Britt, T. W., \& Greene-Shortridge, T. M. (2012). Organizational work-family resources as predictors of job performance and attitudes: The process of work-family conflict and enrichment. Journal of occupational health psychology, 17(1), 28.

Pujiono, J. S. (2016, Oktober 03). Mengapa perempuan lebih puas dengan pekerjaannya. Beritagar.id. Retrieved from https://beritagar.id/artikel/gaya-hidup/mengapaperempuan-lebih-puas-dengan-pekerjaannya. 
Rathi, N., \& Barath, M. (2013). Work-family conflict and job and family satisfaction: Moderating effect of social support among police personnel. Equality, Diversity, and Inclusion: An International Journal, 32(4), 438-454.

Sarker, S. J., Crossman, A., \& Chinmeteepituck, P. (2003). The relationships of age and length of service with job satisfaction: an examination of hotel employees in Thailand. Journal of Managerial Psychology, 18(7), 745-758.

Spector, P. E. (6 ${ }^{\text {th }}$ Ed.). (2012). Industrial and Organizational Psychology. Hoboken: John Wiley \& Sons Straub, C.
(2012). Antecedents and organizational consequences of family supportive supervisor behavior: A multilevel conceptual framework for research. Human Resource Management Review, 22(1), 15-26.

Weiss, D. J., Dawis, R. V., England, G. W., \& Lofquist, L. H. (1967). Manual for the Minnesota Satisfaction Questionnaire. Work Adjustment Project Industrial Relations Center: University of Minnesota 